\title{
Eficácia de Ácidos Orgânicos na Sobrevivência da Escherichia coli em Caldo Vegetal de Alface (Lactuca sativa L.)
}

Geany Targino de Souza (I), Jessica Bezerra dos Santos Rodrigues (I), Rayssa Julliane de Carvalho (I), Neyrijane Targino de Souza (I), Kataryne Árabe Rimá de Oliveira (I), Rilavia Almeida Lima (I), Evandro Leite de Souza (I), Maria Lucia da Conceição (I)

(I) UFPB - Universidade Federal da Paraíba (Cidade Universitária, s/n - 58051-900 - Castelo Branco, João Pessoa - PB, Brasil)

\section{Resumo}

A incidência de micro-organismos em vegetais, in natura ou processadas tem sido considerada veículos potenciais de um ou mais micro-organismos patogênicos envolvidos em surtos, em especial, por Escherichia coli. Este estudo objetivou investigar a eficácia de diferentes sanitizantes químicos e orgânicos sobre o crescimento da Escherichia coli sp em caldo da alface (Lactuca sativa L.). A cultura de E. coli foi isolada em Agar Eosina Azul de Metileno (EMB) a $35 \pm 0,2^{\circ} \mathrm{C} / 24$ horas e confirmada pelos testes do INVIc (Indol, Vermelho de metila, Voges-Proskauer e Citrato) e reservada para a atividade antimicrobiana. $\mathrm{O}$ caldo da alface foi preparado a partir de folhas íntegras, higienizadas, cortadas assepticamente na proporção de 1:10, triturado, filtrado à vácuo e volumes de $10 \mathrm{~mL}$ em tubos de ensaios e esterilizados a $121^{\circ} \mathrm{C}$ por $15 \mathrm{~min}$. Após resfriamento foi adicionado a cada tubo $1 \mathrm{~mL}$ da cultura teste com a concentração inicial $7 \log \mathrm{UFC} / \mathrm{mL}$, elegendo um tubo controle e nos demais, adicionou-se a suspensão soluções dos antimicrobianos: de vinagre de álcool, ácido acético glacial e ácido cítrico (Limão) à 0,2, 0,5 e 1,0\%, respectivamente e, contagem bacteriana realizada nos tempos de contato Zero, 10, 20 e 30 minutos. Os resultados demonstraram que o vinagre de álcool apresentou ação até 10 minutos nas concentrações 0,2 e $0,5 \%$, proporcionando a redução de 2,5

\footnotetext{
Referência:

Geany Targino de Souza, Jessica Bezerra dos Santos Rodrigues, Rayssa Julliane de Carvalho, Neyrijane Targino de Souza, Kataryne Árabe Rimá de Oliveira, Rilavia Almeida Lima, Evandro Leite de Souza, Maria Lucia da Conceição. Eficácia de Ácidos Orgânicos na Sobrevivência da Escherichia coli em Caldo Vegetal de Alface (Lactuca sativa L.). In: Anais do 12 Congresso Latinoamericano de Microbiologia e Higiene de Alimentos - MICROAL 2014 [= Blucher Food Science Proceedings, num.1, vol.1]. São Paulo: Editora Blucher, 2014. DOI 10.5151/foodsci-microal-340
} 
$\log \mathrm{UFC} / \mathrm{mL}$, com ácido acético glacial a atividade foi verificada à $0,5 \%$ de 10 a 30 minutos com redução até $2,4 \log \mathrm{UFC} / \mathrm{mL}$. A eficácia do ácido cítrico (Limão) contra E. coli constatou uma atuação reduzida desse sanitizante, tendo em vista que não foi visualizada redução da população bacteriana a níveis significativos a E. coli, uma vez que ocasionou a diminuição de apenas $0,4,1$ e 1,2 $\log \mathrm{UFC} / \mathrm{mL}$ nas concentrações $0,2,0,5$ e $1 \%$, respectivamente. Com relação ao ácido cítrico constatou-se pouca influência desse ácido sobre a população de E. coli, não sendo observado redução a níveis significativos, ocasionando a inibição na ordem de $0,4,1$ e $1,2 \log \mathrm{UFC} / \mathrm{mL}$ correspondendo as concentrações $0,2,0,5$ e $1 \%$, respectivamente. Do exposto, conclui-se que vinagre de álcool e ácido acético apresentaram maior eficácia sobre o crescimento da Escherichia coli sp à níveis significativos, ambos na mesma concentração e reduções semelhantes.

Palavras-Chave: Bactéria patogênica , Soluções químicas, Soluções orgânicas, Vegetal

\section{Agência de Fomento:}

